\title{
Indigenous Knowledge, Ecology, and Evolutionary Biology
}

Raymond Pierotti. 2011. Routledge (Taylor \& Francis Group), New York. Pp. Xv + 264, Bibliography, index. ISBN13: 978-0-415-87924-8 (hbk), 978-0-203-84711-4 (ebk).

\author{
Reviewed by E. N. Anderson ${ }^{1}$ \\ Reviewer Address: ${ }^{1}$ Department of Anthropology, University of California, Riverside, Riverside, California 92521
}

Raymond Pierotti is both a sophisticated veteran field biologist and a scholar of Native American cultures and worldviews. This combination has allowed him to develop a rather unique view of the natural world and our place in it as humans.

This book consists of eleven essays, treating different topics related to Native American views of the nonhuman world. Perhaps the best way to review it is to select common themes and general conclusions. The most summary statement in the book is probably the following: "A common general philosophy and concept of community appears to be shared by all of the Indigenous peoples of North America, which includes: 1) respect for nonhuman entities as individuals, 2) the existence of bonds between humans and nonhumans, including incorporation of nonhumans into ethical codes of behavior, and 3) the recognition of humans as part of the ecological system" (pp. 198-199). These three themes receive much elaboration. In regard to the first, Pierotti notes that his experience as a field biologist confirms the considerable differences that can occur between individuals in the same population of mammals or birds. Some are stunningly successful reproducers, some fail. Some are terrific hunters or fighters or foragers, others (most) are not. Biologists with little field experience tend not to realize this, and to think of all animals of one species as interchangeable (in spite of Darwin). Of course any good field biologist learns to pick up on individual differences eventually — think of Jane Goodall's work-but certainly having a Native American outlook helps.

In regard to the second, humans and nonhumans are also related religiously and socially; they share one communitas in Victor Turner's terms, and other-thanhuman persons are typically incorporated in kinship systems. This is not so much a matter of projecting human society on nature (as early-day social scientists argued) but of seeing society as fully incorporating both human and other-than-human persons. Wider kinship groups like moieties and clans naturally include both. This may be metaphoric; Pierotti sees much of the religious discourse on animals as metaphoric and based on empirical observation, rather than as irrational mystical belief.

As to the third, Pierotti critiques the almost universal tendency of biologists to see humans as intruders, disruptors, or plain outsiders to ecosystems, in spite of the fact that humans have been in the Americas for at least 13,000 years (and probably longer), and evolved in Africa over millions of years. Even in the Americas, that gives plenty of time for humans to have influenced the evolution of even quite slow-breeding animals, let alone annual plants. Humans have influenced all earthly ecosystems profoundly, and outside of the polar regions these influences are long-standing. This leads to the further point that Euro-American science has very many blinders, biases, and wrong assumptions of its own, and is hardly in a position to condemn other scientific traditions for whatever errors they may have. (The present reviewer sometimes tries to count up how many of the great scientific truths I learned in high school and undergraduate education have been disproved since. I never finish the list because I lose count.)

Other themes recur frequently but are foregrounded in particular chapters, to which we may now turn. The first defines traditional knowledge, noting (among other things) that traditions are dynamic, changing and keeping up with the times. The idea of "tradition" as static and archaic is simply silly. Many other terminological issues are raised here, including the problem with "supernatural" in societies that do not separate natural from supernatural. Are wolves and coyotes supernatural because they (mythically) helped with creation (in a possibly 
metaphoric sense)? Or are they natural, with some dubious powers attributed to them?

The second essay, "All Things are Connected," develops points two and three above. Pierotti also points out that Native Americans, in common with modern ecologists but not with early-day ones, see the world as dynamic, contingent, and constantly changing, rather than as always in stable harmony and balance except during brief "disruptions." Native Americans can thus deal more easily with things like fluctuating fish populations, rather than seeking for an illusorilyexact "maximum sustained yield" figure that turns deadly when fishermen fish up to it even when natural fluctuation leads to a population crash. Pierotti then speculates, interestingly, on the roles of plagues in causing population changes but also in conditioning human thought about nature.

The third, "Predators Not Prey," develops the point that Native Americans tend to identify with-or at least foreground in myth-the predators: wolves, coyotes, bears, eagles, and others. The European world often fears and hates predators and identifies with its animal wards, as in the countless Judeo-Christian metaphors involving lambs and sheep. Europeans love domestic predators, but not wild ones. This has led to mistaken biology; again, an older generation tended to see predators as disruptive and ravaging, not part of the natural order. It is quite amazing to read old sources condemning birds like Cooper's hawks for "cruelly" taking songbirds, or to see the flak that Aldo Leopold endured for suggesting that wolves had a place in nature.

Chapter 4, "Metaphors and Models" develops the point that a great deal of what seems like "religious" or "mythic" discourse to the outsider can be understood as metaphoric discourse based on how animals really act. Mythic wolves and eagles act more or less like real ones, and the "keepers of the game" universally known in North America (including among my Maya friends in Mexico, I may point out) appear to be based on the recognition that some animals are super-successful at breeding, hunting, or other activities. In many species, a few individuals in a population contribute disproportionately to the gene pool. Conversely, European biology is also based on models, especially the infamous statement of Descartes that animals are mere soulless machines (Descartes 2003:40). This led to ignoring complexity, will, individuality, and mentation in animal behavior, and by further extension to the harmony-and-balance errors in accounts of ecology in general.
The fifth essay deals with creation and evolution; some Native American authors have attacked the theory of evolution, based on poor understandings of it, and Pierotti defends it while showing that Native American creation stories are quite evolutionary in thinking. The sixth discusses ways of applying traditional knowledge in Euro-American science. This will probably be the most interesting essay to a biologist, because Pierotti discusses many of his research findings and shows how they fit with Native American science but not with European-largely because of the "individual difference" point raised above, but there is much more here, including several examples of high intelligence or of completely inexplicable but complex actions by other-than-human persons. Clearly, biologists need the Native American eye. The seventh, "Connected to the Land: Nature and Spirit in Native American Novels," discusses the views on nature reflected in recent Native American novels. It seems to me a superb example of literary reading, but I am not competent in the field, so will leave it to better qualified persons to assess.

The eighth, "Ecological Indians," critiques several inaccurate portrayals of Native American ecology, especially Shepard Krech's The Ecological Indian (1999) on grounds that should be familiar to readers of this newsletter (cf. my review, Anderson 2000). This essay is long and detailed, and should be required reading for anyone writing on this subject; it is a particularly sensitive and thorough analysis of the truth as opposed to the various stereotypes. The ninth essay extends the same degree of thorough analytic criticism to Vine Deloria's creationist ideas and some of his other shaky views on Native American matters. Pierotti expresses surprise that Deloria, usually a defender of Indigenous views, has accepted fundamentalist Christian ideas closely associated with genocidal and culturocidal policies toward Indigenous peoples. The rather briefer tenth and eleventh essays (previously published in shorter versions) call for renewed defense of otherthan-humans in this world of mass destruction (human as well as other), and for much more study, use, and application of traditional ecological knowledge.

Overall, this book is one of the most impressive, unique, and thoroughly documented discussions of Native American ecological thinking. Pierotti uses a wide range of quotes, and is extremely literate in everything ranging from state-of-the-art biology to novels and poetry. The book stays at a uniformly high level of analytic and theoretical sophistication. It is convincing and important. It is absolutely necessary reading for anyone interested in Native American views 
of and theories about the natural or other-than-human world and humanity's place therein.

Criticisms are few. Possibly the most thoughtful would be that "wilderness" in our popular sense (of a truly wild place-not our sense of "scary" or "bad") was not an unknown concept before Columbus: young men seeking visions were expected to go as far from humans as they could get, stay in some remote place among dangerous wild animals, and purify themselves, learn courage and self-reliance, and become strong both physically and spiritually in that solitude. This not only parallels our concept, it may even have inspired it, via the idealization of the "wilderness experience" by people like Theodore Roosevelt and John Muir. They had associated with Native Americans in the wild, and to my knowledge they were the first to use this sort of rhetoric in English. Perhaps Pierotti drives the "metaphor" concept a bit beyond its scope; Native American ideas of nature can certainly be seen that way now, but, equally certainly, people (Europeans as much as Native Americans) of a few centuries ago believed many things to be factual (not just metaphoric) that we would now consider dubious. There is also one rather surprising error in the book (p. 43): Pierotti accepts the theory that the Aztecs ate their sacrifices because of lack of protein. This idea was refuted as soon as published (see Ortiz de Montellano 1990) and has no basis in fact.
Aside from these trivial notes, this book is an astonishing achievement, covering a wide range of subjects with ease and grace as well as accuracy and depth. It shows that Native Americans were hardheaded scientists as well as poets and mythmakers. They were not romantic noble savages, but were highly competent and successful users of the environment. They constructed knowledge systems that are not only interesting in their own right, but are vitally important today. The survival of humanity may depend on using their extensive and thorough understandings.

Thanks to Ray Pierotti for help with this reviewfull disclosure: I checked it with him for accuracy. Any problems and errors remain entirely mine.

\section{References Cited}

Anderson, E. N. 2000. The Ecological Indian by Shepard Krech. Journal of Ethnobiology 20:37-42.

Descartes, René. 2003. Discourse on Method and Related Writings. Tr. Desmond Clarke (French original 1637). Penguin, New York.

Krech, Shepard, III. 1999. The Ecological Indian: Myth and Reality. W. W. Norton, New York.

Ortiz de Montellano, Bernard R. 1990. Aztec Medicine, Health, and Nutrition. Rutgers University Press, New Brunswick, NJ. 